\title{
The Flight: Depiction of the American Dream in Tennessee Williams' Sweet Bird of Youth
}

\author{
Kadavakollu Tejaswani, Ph. D.
}

\section{Introduction to the American Dream:}

The United States of America's Declaration of Independence proclaims that 'life', 'liberty' and 'pursuit' of happiness are rights of individuals irrespective of their personal background. Most Americans believe that success can be achieved through hard work. Unfortunately, the American Dream was also distorted by certain people in the sense they aim at pursuing their individual happiness at the cost of harming the interests of others involved.

An interesting aspect in American literary history is how the American Dream was portrayed by various playwrights coming from different backgrounds in the 1920s. Scott F. Fitzgerald in his The Great Gatsby (1925) reveals that America was materialistically rich with liquor, power, sex, and money flowing freely all over America [1]. Playwrights Tennessee Williams (Thomas Lanier Williams), Arthur Miller, and Lorraine Hansberry coming from different backgrounds reveal their own interpretation of the American Dream. In "The Glass Menagerie," (1944) the American Dream for white Americans is portrayed as a pursuit of individual happiness though in the end Tom Wingfield fails to reach his goal. In Arthur Miller's "The Death of a Salesman," (1949) the American Dream of Willy Loman's misconceived notion that superficial qualities like personal attraction and popularity among his peers will assure success for his family falls flat [3]. In Hansbery Lorraine's "A Raisin in the Sun," (1959) Mama's American Dream is to keep her family together and uphold the family values [2]. For an African American family, after centuries of slavery, abuse, and losing their family members, keeping the family together becomes a priority in their life. In the same period, it is striking to see playwrights and writers of a country belonging to different race, class and gender interpret and work towards their own version of American Dream.

\section{Introduction to Tennessee Williams:}

Tennessee Williams was born in 1911. He was a major playwright who represented the contemporary times of America and his works also included novels, short stories, poems, essays and screenplays. Some of his popular plays are The Glass Menagerie (1944), A Streetcar Named Desire (1947), Summer and Smoke (1948), The Rose Tattoo (1951), Cat on a Hot Tin Roof (1955), Orpheus Descending (1957), and The Night of the Iguana (1961). His later works were not well received by the critics and audience as well, in fact many of them failed to deliver at the box office. Many reasons could be attributed to this, one being that Tennessee Williams' interest in poetry which manifested in the playwriting as well and the other his dwindling reputation due to his alcohol and drug dependence. Irrespective of the negative reviews and adverse criticism regarding his approach he kept writing so as to introduce an innovative and artistic approach to playwriting. His last play was 'A House Not Meant to Stand' in 1982 just before his death in 1983. At the time of his death, he was working on the play 'In Masks Outrageous and Austere'.

\section{Background to the play:}

Around the end of the Second World War (1939 - 45), American playwrights mainly focused on themes like alcoholism, violence, sexuality, homosexuality, rape, and fetishism which were previously considered as taboo issues to be staged as plays. Tennessee Williams was writing at the time when America was in a crisis created by Depression and World Wars I and II. Most of the people at that time were disillusioned due to the troubled times and unemployment. Due to the great Depression, many people lost their jobs which resulted in loss of confidence in themselves. People were disillusioned and depressed due to the economic conditions in the country. A few people could direct their problems into creative channels. Tennessee Williams was one such individual who channelized his weakness into creative avenues.

The present play 'Sweet Bird of Youth' was actually written in 1956 and was a combination of two plays, one was a two-character play with only two characters, Chance Wayne and Princess Kosmonopolis who is also known as Alexandra Del Lago and the other was a one-act play featuring Boss Finley and his family. In 1959 , these two plays were combined to produce a three-act play. There were at least eight versions of this play written by Tennessee. Tennessee received positive as well as negative criticism for this play. Some critics 
hailed his expertise in language and characterization whereas some critics flayed this play as disjointed and disorganized. Acclaimed author, Drewey Wayne Gunn opines that this is one play of Williams which through its repeated revisions "represent rather a sequential degeneration of Williams's artistic control, for in each revision the structure, the development of the characters, and the focus of the play become progressively less coherent. [6]

Another important aspect is William Inge's secretary, John Connolly's implication, that there are striking similarities in the plot and construction of the plays 'Sweet Bird of Youth' and Inge's 'Bus Riley's Back in Town.' The implication could be pure speculation as Williams and Inge were great friends in the 1950s and though they used to read their rough drafts to each other, it is not possible to assert that the idea was copied by any one of them as the plays were based on centuries' old theme of young lovers separated by warring families, i.e. Romeo and Juliet by Shakespeare to which authors in the present day also add their own observations and experiences [7].

\section{Themes of Tennessee Williams:}

Tennessee Williams is recognized as the innovator of the New American Drama based on his plays on topics related to men and women who were unable to help themselves. His main characters like Tom Wingfield have biographical elements. Highly observant and analytic, Tennessee Williaws based the characters in his plays like Amanda, Laura, Jim O'Connor, Stanley Kowalski, Big Daddy, Big Mama, Brick and Maggie on people he personally knew in his life [5].

Williams's main characters are individuals who are in search of their identity. Some of these characters demonstrate characteristics that could be a consequence of repressed sexuality. Williams was also affected by his father's frequent absences as he was a travelling salesman and his dominating and controlling behaviour when at home. Due to this atmosphere at home, he became attached to his mother and sister. His feelings are candidly manifested in his characters. Over the years, many psychoanalytical interpretations are inferred from his plays.

Mental anguish to a great extent and physical violence to a certain level have been a central part of his plays. Though critics argue that his drinking and drug taking combined with his fear of going insane could be the rationale behind the inclusion of violence both physical and mental in his themes, he could also be reflecting the milieu of the times. But again the acceptance of this violence by critics and audience left Tennessee totally surprised. He says in the foreword of 'Sweet Bird of Youth:'

"What surprises me is the degree to which both critics and audience have accepted this barrage of violence. I think I was surprised, most of all, by the acceptance and praise of Suddenly Last Summer. When it was done off Broadway, I thought I would be critically tarred and feathered and ridden on a fence rail out of New York theatre, with no future haven except in translation for theatres abroad, who might mistakenly construe my work as a castigation of American morals, not understanding that I write about violence in American life only because I am not so well acquainted with the society of other countries." [5]

Violence, struggle for power, passion, viciousness, sex, deceit, homosexuality were openly portrayed in his plays. Williams confessed that he was portraying human weaknesses in his plays but at the same time also candidly accepted that he was staging only those experiences that he himself went through. He quotes "I can't expose a human weakness on the stage unless I know it through having it myself. I have exposed a good many human weaknesses and brutalities and consequently I have them" in the foreword of his play Sweet Bird of Youth [5].

Williams juxtaposes 'gain and loss' and 'loss and gain' in this play where the play also demonstrates themes like 'desire and aftermath' and 'procreation and castration.' The play portrays sexual degradation and psychological dysfunctions of power-hungry people. It also can be rightly said that the play is about 'loss of innocence' and 'perception of responsibility.' 1950s America was about power, sex and money, where all three were equally important for the disillusioned youth as portrayed in the literature of that era. The degradation of that period was probably due to the affect of Wars and the Great Depression. By the end of the play, the readers realize that the great American Dream as a goal has lost its importance in a world which tries to achieve it through questionable means.

\section{Significance of the title of the play:}

Williams could probably be hinting on the pleasurable and optimistic quality of youth when he titled the play as 'Sweet Bird of Youth.' Sweet though it is, it can turn acidic when expended in an erratic and irresponsible manner. Also, by the time we realize its significance and are in need of it, this sweet bird flies away. Not only was Williams portraying the times in his play, he was also incorporating autobiographical 
elements into it as well. Unknowingly and unintentionally, he was also moralizing, as the play seems to affirm that irresponsible and immoral behaviour results in drastic consequences. He also quotes Aristotelian idea that violence is purged by its poetic representation on the stage (Bird 7).

Summary:

The play is set in St. Cloud, Florida. Chance Wayne works as a waiter in Boss Finley's club. There he meets Finley's daughter, Heavenly, and falls in love with her. Chance tries to seek Finley's consent to go out with Heavenly. Finley does not like the idea of his daughter getting married to a waiter. So, he manipulates Chance into leaving the town by enticing him with the American Dream. He urges Chance to seek fame and fortune in Hollywood. Chance fails to make it in Hollywood; instead he ends up as a gigolo. He comes back with an ageing actress, Princess Kosmonopolis to St. Cloud to help her escape negative publicity of a movie role. He wants to use Princess Kosmonopolis to get a hold in Hollywood. But he realizes that he infected Heavenly with a venereal disease. In spite of knowing the severity of the punishment, i.e. castration, he decides to stay back and face the consequences of his irresponsible behaviour.

\section{Writing Style of Tennessee Williams:}

In the period before 1944, Williams tried to portray what reality was like. But in his plays after 1944, he tried to look into the reasons behind the reality. In his later plays like A Glass Menagerie (1945), A Streetcar Named Desire (1947), and Outcry (1973), readers can recognize Williams's efforts to get behind the facade of humanity. His technique of paying attention to expression sans language emerges effortlessly as seen in his later plays. Williams shifted his focus to playing with the inexpressible as a result of which we see him using silences, pauses, gaps and an indistinct dialogue style using short and concise sentences and sometimes incomplete sentences to imply the unexpressed. He also expertly uses techniques from absurd theatre to represent realistic views in his plays.

\section{Representation of American Dream in Sweet Bird of Youth:}

The two main characters, Chance Wayne and Alexandra Del Lago represent the citizens in quest of realizing the great American Dream. But unfortunately they are unscrupulous in their quest to achieve their goals. Goaded by Boss Finley, the rich father of the girl he loves, Chance Wayne dreams of becoming a Hollywood star. He does not comprehend Finley's scheme to try to get him out of Heavenly's life.

The troubled times do have a powerful impact on American youth as many of them are disillusioned, immoral and corrupt. They do not have any qualms regarding the means to achieve their ends. Chance Wayne tries to use sex with established actors to weave his way through Hollywood. In fact he tries blackmail and sexual favours with Del Lago to promote him as an actor.

Alexandra Del Lago is a fading star who attempts to hide after what she thinks was a disastrous performance in a movie. She relies on drugs and drinking to get her through trying times. She relies on Chance as his love for her temporarily makes her feel young. The movie, surprisingly, receives critical acclaim and she is exultant. She represents individuals who are unstable and insecure at the helm of success. Circumstances influence this sort of individuals who are unable to control their emotions and are dependent on external stimulants to calm them. At the end of the play, she offers to help Chance to get away from an impending punishment for his role in ruining Heavenly.

Boss Finley is a character who uses power, money and sex to accomplish his goals and his goal is to separate his daughter, Heavenly and Chance Wayne, a waiter in his club who fall in love with each other. He manipulates Chance into believing that he can become a Hollywood star if only he tried. He tries to keep him away from his young daughter as he does not want her to get married to a person who belongs to the working class.

Again, we cannot totally say that all Williams's characters are totally debased. At the end of the play, Chance, decides to stay back and be punished by Finley's men in spite of knowing that the punishment is castration. Del Lago, despite knowing the facts, offers to help Chance an escape from the town. Compassion and taking responsibility for their rash actions seems to come naturally to some characters in Williams's plays. Williams's empathetic nature surfaces through this change in his characters' perceptions.

Williams, in this play, seems to be focusing on loss of innocence in the youth and the price of success in life. And irrespective of everything, time seems to fly unwaveringly on its path. Time has the power to question success as seen in the characterization of Chance Wayne, time has the power to transform a reigning star into a fading star as seen in the characterization of Del Lago. Time has the power to change the priorities of Chance Wayne's American Dream into matured redemption. In truth, Chance and Heavenly's love for each other emerged constant, steadfast and strengthened notwithstanding the trying times. Moreover, by the end of the play, Chance, Heavenly and Del Lago realize that standing for what they believe as right is more important than pursue the American Dream through scrupulous means. 


\section{References:}

[1] Fitzgerald, Scott F. The Great Gatsby. 1925. New York: Charles Scribner's, 1953.

[2] Hansberry, Lorraine. A Raisin in the Sun. 1958. New York: Random, 1966.

[3] Miller, Arthur. Death of a Salesman. 1948. New York: Dramatists Play Service, 1980.

[4] Williams, Tennessee. The Glass Menagerie. 1945. New York: Dramatists Play Service, 1975.

[5] - - -. Sweet bird of youth: A streetcar named Desire ; The glass menagerie. New York:

[6] http://ww.tennesseewilliamsstudies.org/archives/2002/1panel_lateplays.pdf, $01^{\text {st }} \mathrm{Jan}$., 2013.

[7] http://www.thefreelibrary.com/Tennessee+Williams's+Sweet+Bird+of+Youth+and+ William+Inge's+Bus...-a0141995707 $11^{\text {th }}$ Jan., 2013

[8] http://www.questia.com/library/1G1-141995707/tennessee-williams-s-sweet-bird-of-youth-and-william, $7^{\text {th }}$ Jan., 2013.

[9] http://www.angelfire.com/home/qaf/sweetbird.html, $11^{\text {th }}$ Jan., 2013

[10] http://www.tennesseewilliamsstudies.org/archives/2007/08panel_inge.html, $12^{\text {th }}$ Jan., 2013. 